\title{
FTIR Study of Carbon Dioxide Interaction with some Room Temperature Ionic Liquids
}

\author{
Hadi M. A.Abood and Evon Akram \\ Department of Chemistry, College of Science, University of Al-Nahrain, Baghdad-Iraq.
}

\begin{abstract}
Four ionic liquids were investigated for abilities to capture $\mathrm{CO}_{2}$ alone or with added catalyst at room temperature and atmospheric pressure. Hydrated aluminum nitrate $\mathrm{Al}\left(\mathrm{NO}_{3}\right)_{3} .9 \mathrm{H}_{2} \mathrm{O}$-urea with added $\mathrm{CaO}$, hydrated ammonium aluminum sulfate $\mathrm{NH}_{4} \mathrm{Al}\left(\mathrm{SO}_{4}\right)_{2} .12 \mathrm{H}_{2} \mathrm{O}$-urea with added solid $\mathrm{NaOH}$ did not show in FTIR chart sign of either physical or chemical absorption of $\mathrm{CO}_{2}$, however hydrated ammonium aluminum sulfate $\mathrm{NH}_{4} \mathrm{Al}\left(\mathrm{SO}_{4}\right)_{2} \cdot 12 \mathrm{H}_{2} \mathrm{O}$-urea with added $\mathrm{NaOH}_{\mathrm{aq}}$ or few water showed a chemical absorption of $\mathrm{CO}_{2}$ at $1666 \mathrm{~cm}^{-1}$ as in aluminum chloride-urea ionic liquid while aluminum chloride-acetamide showed weaker or no ability to capture $\mathrm{CO}_{2}$.
\end{abstract}

Keywords: Ionic liquids, Carbon dioxide capture, Catalysts, FTIR.

\section{Introduction}

One of the interesting gases which represent important problem in the atmosphere is carbon dioxide. Its concentration has been increased from $280 \mathrm{ppm}$ at the beginning of the industrial (Ca.1750) to $390 \mathrm{ppm}$ in $2010^{[1]}$. The increased concentration of $\mathrm{CO}_{2}$ in atmosphere influences the balance of incoming and outgoing energy in the atmosphere system, leading to raise the average surface temperature of earth. Thus, $\mathrm{CO}_{2}$ has often been cited as the primary anthropogenic greenhouse gas (GHG) as well as the leading culprit in climate change. The reasons for this skewed reliance on fossil fuels as our primary energy source is due to the inherent energy density, abundance and the economic dependence of modern society on the acquisition and trade of these resources ${ }^{[1,2]}$.

One of the mostly studied solvent used to capture $\mathrm{CO}_{2}$ is monoethanolamine (MEA) which has some advantages such as its maturity, stable operation, good reactivity, and high capacity ${ }^{[3]}$. (MEA) $\mathrm{CO}_{2}$ capture consumes almost $30 \%$ of the energy that is needed to run a power plant ${ }^{[4]}$, in addition to other drawbacks like, high solvent losses caused by evaporation, degradation and poor thermal stability, as well as equipment corrosion ${ }^{[4,5]}$. Therefore, developing an economical and energy efficient $\mathrm{CO}_{2}$ capture technologies is highly needed. Ionic liquids ILs constitute a new class of solvents which are also known to be selective for $\mathrm{CO}_{2}$ absorption ${ }^{[6,7]}$.
Carbon dioxide was reported to have solubility commonly higher in ILs with fluoroalkyl groups such (tris (trifluoromethylsulfonyl) methide, [methide], and bis (trifluoromethylsulfonyl) imide, $\left.\left[\mathrm{Tf}_{2} \mathrm{~N}\right]^{-}\right)$and lower in ILs with non-fluorinated inorganic anions such as (nitrate, $\left[\mathrm{NO}_{3}\right]^{-}$, and dicyanamide, $\left.[\mathrm{DCA}]^{-}\right)^{[8]}$.

The general mechanism of $\mathrm{CO}_{2}$ absorption in ionic liquids could be described as physical or chemical process Ionic liquids comprise combinations of large organic cations and smaller inorganic anions and are typically viscous liquids near room temperature ${ }^{[9]}$.

In addition to their extremely low vapor pressures, they are non-flammable, environmentally benign, and can exhibit exceptional thermal stability. The mechanism for $\mathrm{CO}_{2}$ capturing is often based on physisorption, and involves weak association between the ionic liquid and $\mathrm{CO}_{2}$ molecules (rather than chemical bonds), with heats of adsorption of around $\left(11 \mathrm{kJmol}^{-1}\right)^{[10,11]}$. In view of this low heat of reaction, the obvious benefit for $\mathrm{CO}_{2}$ capture is the minimal energy required for solvent regeneration. The capacity is directly proportional to the partial pressure of $\mathrm{CO}_{2}$ and improves at pressures above 1-2 bar. For this reason, ionic liquids were initially proposed for pre -combustion applications. Some ionic liquids react with $\mathrm{CO}_{2}$ in a chemisorption mechanism. This is an additional benefit as that ionic liquids can simultaneously serve to remove $\mathrm{CO}_{2}{ }^{[12]}$. 
In amine functionalized ionic liquids, the mechanism considered as chemical process. Therefore it was found that the careful choice of the ionic liquids and its properties and profound knowledge of the molecular features seem to be the way to proceed in order to find ionic liquids appropriate for carbon dioxide selective absorption ${ }^{[9]}$.

The work of this paper covered the ability of some ionic liquids to absorb $\mathrm{CO}_{2}$. The investigation of $\mathrm{CO}_{2}$ absorption was followed by FTIR technique. Ionic liquids containing urea were found to be good solvent for some metal oxides particularly those of room temperature ionic liquids with aluminum chloride, aluminum sulfate, aluminum nitrate or containing choline chloride. Additionally, aluminum chloride- acetamide ionic liquid was also used in this study to elucidate its capability to absorb $\mathrm{CO}_{2}$.

\section{Experimental Work}

Materials. $\mathrm{NH}_{4} \mathrm{Al}\left(\mathrm{SO}_{4}\right)_{2} .12 \mathrm{H}_{2} \mathrm{O} 99 \% \mathrm{BDH}$, $\mathrm{Al}\left(\mathrm{NO}_{3}\right)_{3} .9 \mathrm{H}_{2} \mathrm{O} 97 \% \mathrm{BDH}, \mathrm{AlCl}_{3} 98 \%$ Fluka, $\left(\mathrm{NH}_{2}\right)_{2} \mathrm{CO} 99.5 \%$ THOMAS BAKER, $\mathrm{NaOH}$ $99 \% \mathrm{BDH}, \mathrm{CaO} 99 \% \mathrm{BDH}, \mathrm{NH}_{2} \mathrm{COCH}_{3} 98 \%$ Fluka chemical were used.

\section{Instrument}

The main instrument used throughout this study was FTIR (Fourier Transform Infrared Spectrophotometer, 2006, Shimadzu, IR-Prestige 21).

\section{1-Preparation of ionic liquids}

a- Hydrated ammonium aluminum sulfate $\mathrm{NH}_{4} \mathrm{Al} \quad\left(\mathrm{SO}_{4}\right)_{2} .12 \mathrm{H}_{2} \mathrm{O}$ and urea $\mathrm{NH}_{2} \mathrm{CONH}_{2}$ in a mole ratio of (1:5) respectively were milled, well mixed and heated gradually to $\left(85^{\circ} \mathrm{C}\right)$ in a closed glass tube with continuous gentle stirring until the solid salts changed to colorless liquid $^{[13]}$.

b- Solid mixture of hydrated aluminum nitrate $\mathrm{Al} \quad\left(\mathrm{NO}_{3}\right)_{3} .9 \mathrm{H}_{2} \mathrm{O}$ and urea $\mathrm{NH}_{2} \mathrm{CONH}_{2}$ in a mole ratio of $(1: 1.3)$ was milled, well mixed and heated gradually to $\left(85^{\circ} \mathrm{C}\right)$ in a close container with continuous gentle stirring until both solid components melted together producing colorless liquid.

c- Aluminum chloride with either urea or acetamide were used to prepare the ionic liquid in a mole ratio of $(1.4: 1)$ by direct mixing of solid components which gave a clear faint liquids $^{[14]}$.

\section{2- Added chemical compounds to ionic liquids.}

Some chemical compounds were added to ionic liquids as powder or aqueous solution:-

a- Sodium hydroxide pellet $(0.04 \mathrm{~g})$ was crashed and added to $10 \mathrm{ml}$ of $\mathrm{NH}_{4} \mathrm{Al}$ $\left(\mathrm{SO}_{4}\right)_{2} .12 \mathrm{H}_{2} \mathrm{O}$-urea ionic liquid.

b- Three drops of sodium hydroxide aqueous solution $(0.002 \mathrm{M})$ was added to $10 \mathrm{ml}$ of $\mathrm{NH}_{4} \mathrm{Al}\left(\mathrm{SO}_{4}\right)_{2} .12 \mathrm{H}_{2} \mathrm{O}$-urea ionic liquid.

c- Calcium oxide $(0.01 \mathrm{~g})$ was added to $10 \mathrm{ml}$ of both $\mathrm{NH}_{4} \mathrm{Al}\left(\mathrm{SO}_{4}\right)_{2} .12 \mathrm{H}_{2} \mathrm{O}$-urea and $\mathrm{Al}$ $\left(\mathrm{NO}_{3}\right)_{3} .9 \mathrm{H}_{2} \mathrm{O}$-urea ionic liquids $(0.0178 \mathrm{M})$ in its powder form.

\section{3-Carbon dioxide gas flow}

Carbon dioxide was bubbled in to ionic liquids at flow rate of $500 \mathrm{ml} / \mathrm{min}$. for half an hour through mesh orifice ended glass tube immersed down the bottom of the reaction tube and at the end of experiment the liquid was examined by FTIR.

\section{Result and Discussion}

Added sodium hydroxide pellet to $10 \mathrm{ml}$ of $\mathrm{NH}_{4} \mathrm{Al}\left(\mathrm{SO}_{4}\right)_{2} .12 \mathrm{H}_{2} \mathrm{O}$-urea IL formed a clear liquid mixture at room temperature $\left(17 \mathrm{C}^{\circ}\right)$ which showed the vibration bands as in Fig.(2) that appeared to have no difference frequency from the vibration bands of the ionic liquid alone Fig.(1) which might indicate an absorption of $\mathrm{CO}_{2}$ in ionic liquid alone or with added $\mathrm{NaOH}$. To enhance the absorption of $\mathrm{CO}_{2}$ by ionic liquid, $\mathrm{NaOH}$ was also added but as aqueous solution. This was though to decrease the viscosity of the mixture due to the presence of water and expected to increase the dissolution of $\mathrm{CO}_{2}$. The FTIR of this mixture shown in Fig.(3) indicated a change in the higher frequencies, particularly of the $\mathrm{N}-\mathrm{H}$ stretching vibrational bands of the urea amine group above $\left(3000 \mathrm{~cm}^{-1}\right)$ and in the lower frequencies in the carbonyl vibrational bands at $1647 \mathrm{~cm}^{-1}$ and $1666-1627 \mathrm{~cm}^{-1}$ as listed in Table (1). This might be related to an interaction of carbon dioxide $\mathrm{CO}_{2}$ with the amine groups affecting their vibration mode and there by influencing the vibrational mode 
of the carbonyl group of urea. It also indicated the importance of reducing viscosity of ionic liquid to improve the interaction of $\mathrm{CO}_{2}$ with amine group where gas diffusion is more feasible.

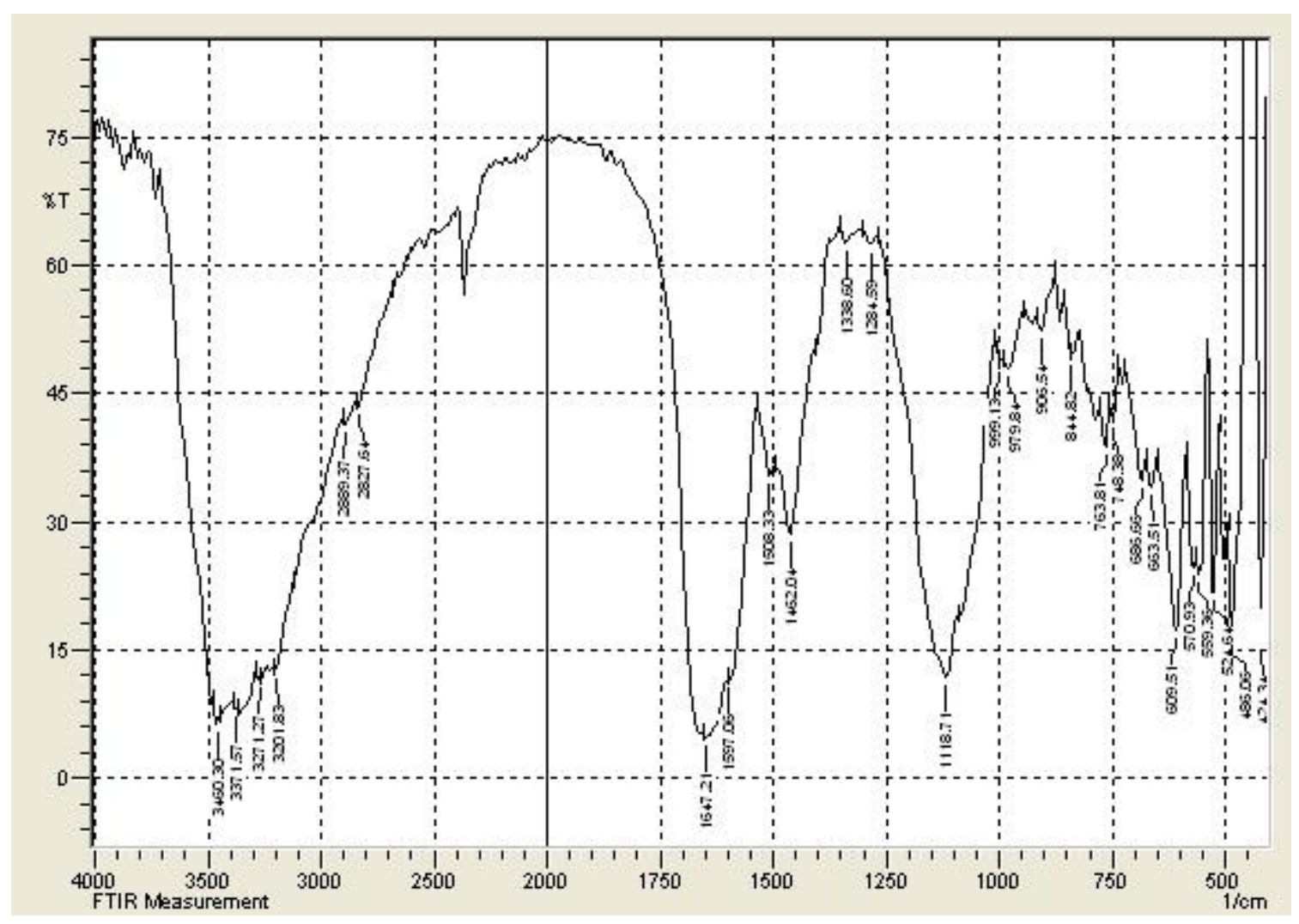

Fig.(1) FTIR spectra of $\mathrm{NH}_{4} \mathrm{Al}\left(\mathrm{SO}_{4}\right)_{2} .12 \mathrm{H}_{2} \mathrm{O}$-urea IL.

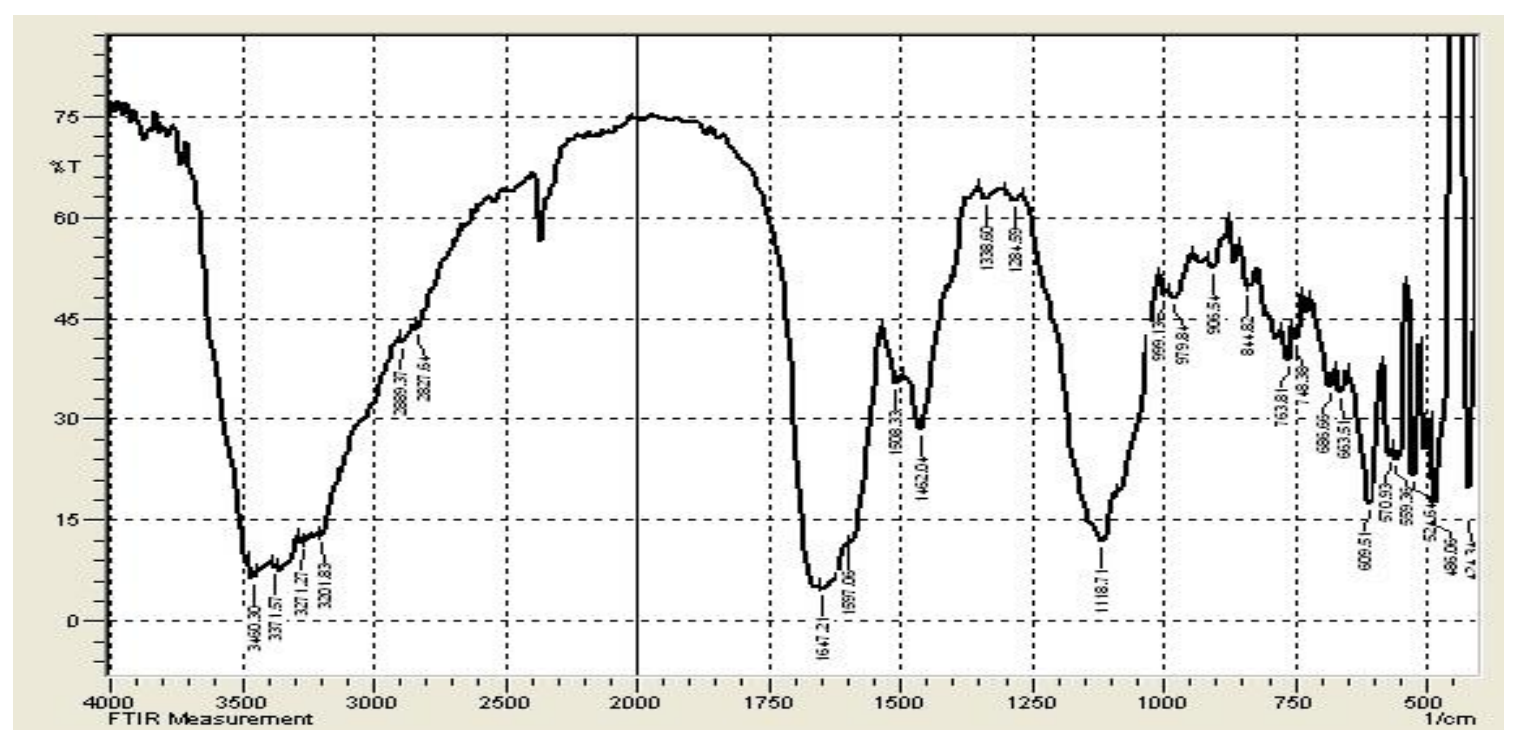

Fig.(2) FTIR spectra of $\mathrm{NH}_{4} \mathrm{Al}\left(\mathrm{SO}_{4}\right)_{2} .12 \mathrm{H}_{2} \mathrm{O}$-urea IL with added solid $\mathrm{NaOH}$. 


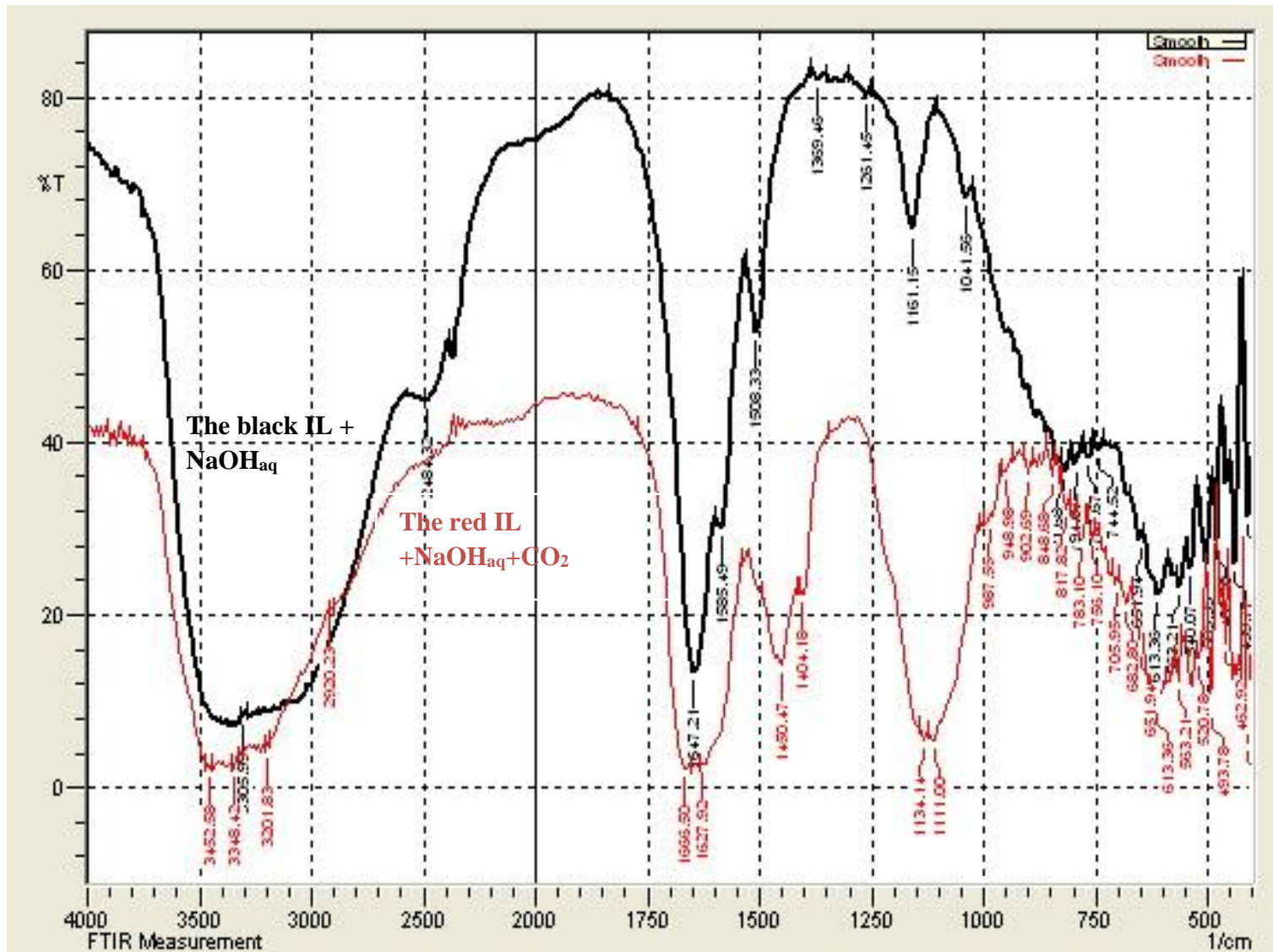

Fig.(3) FTIR spectra of $\mathrm{NH}_{4} \mathrm{Al}\left(\mathrm{SO}_{4}\right)_{2} .12 \mathrm{H}_{2} \mathrm{O}$-urea IL with $\mathrm{NaOH}_{a q}$, the black IL with $\mathrm{NaOH}_{a q}$, the red IL with $\mathrm{NaOH}_{a q}$ after bubbling $\mathrm{CO}_{2}$.

Table (1)

Vibrational bands of the ionic liquid $\mathrm{NH}_{4} \mathrm{Al}\left(\mathrm{SO}_{4}\right)_{2} .12 \mathrm{H}_{2} \mathrm{O}$-urea alone; with added $\mathrm{NaOH}$ aq and with capturing $\mathrm{CO}_{2}$.

\begin{tabular}{|c|c|c|c|c|c|}
\hline$I L$ & $\begin{array}{c}v(N-H) \\
c m^{-1}\end{array}$ & $\begin{array}{c}\delta(N-H) \\
\mathrm{cm}^{-1} \\
\end{array}$ & $\begin{array}{c}v(C=O) \\
\mathrm{cm}^{-1}\end{array}$ & $\begin{array}{c}v_{s}(N-C-N) \\
c^{-1}\end{array}$ & $\begin{array}{c}v_{\text {as }}(N-C-N) \\
\mathrm{cm}^{-1}\end{array}$ \\
\hline $\begin{array}{c}\mathrm{NH}_{4} \mathrm{Al}\left(\mathrm{SO}_{4}\right)_{2} .12 \mathrm{H}_{2} \mathrm{O} . \text { Urea. } \\
\mathrm{NaOH}_{\mathrm{aq}}\end{array}$ & 3305 & $\begin{array}{l}1595 \\
1508\end{array}$ & 1647 & 1161 & 1404 \\
\hline $\begin{array}{c}\mathrm{NH}_{4} \mathrm{Al}\left(\mathrm{SO}_{4}\right)_{2} .12 \mathrm{H}_{2} \mathrm{O} . \text { Urea. } \\
\mathrm{NaOH}_{\mathrm{aq}}+\mathrm{CO}_{2}\end{array}$ & $\begin{array}{l}3452 \\
3348 \\
3201\end{array}$ & 1450 & $\begin{array}{l}1666 \\
1627\end{array}$ & $\begin{array}{l}1134 \\
1111\end{array}$ & 1404 \\
\hline
\end{tabular}

This enhancement of $\mathrm{CO}_{2}$ absorption in this work is in the same trend as number of catalyst systems has also been developed by other workers to increase the efficiency of carbon dioxide absorption by the amine group including added alkali metal salts, ammonium salts, metal oxides, transition metal and main group complexes ${ }^{[15]}$.

Powdered calcium oxide when added made a clear solution with $\mathrm{NH}_{4} \mathrm{Al}\left(\mathrm{SO}_{4}\right)_{2} \cdot 12 \mathrm{H}_{2} \mathrm{O}-$ urea ionic liquid and showed no visible changes until the end of the experiment. The solution showed the FTIR vibration bands as shown in Fig.(4). The N-H stretching frequencies showed an increase in their frequencies when compared with those before bubbling carbon dioxide in ionic liquid. Additionally the carbonyl group also showed similar effect as their frequencies decreased from $1649 \mathrm{~cm}^{-1}$ to $1626 \mathrm{~cm}^{-1}$ Table (2). Both might be considered as an indication of an interaction of carbon dioxide with amine group forming carbamate (N-carbxy urea). 


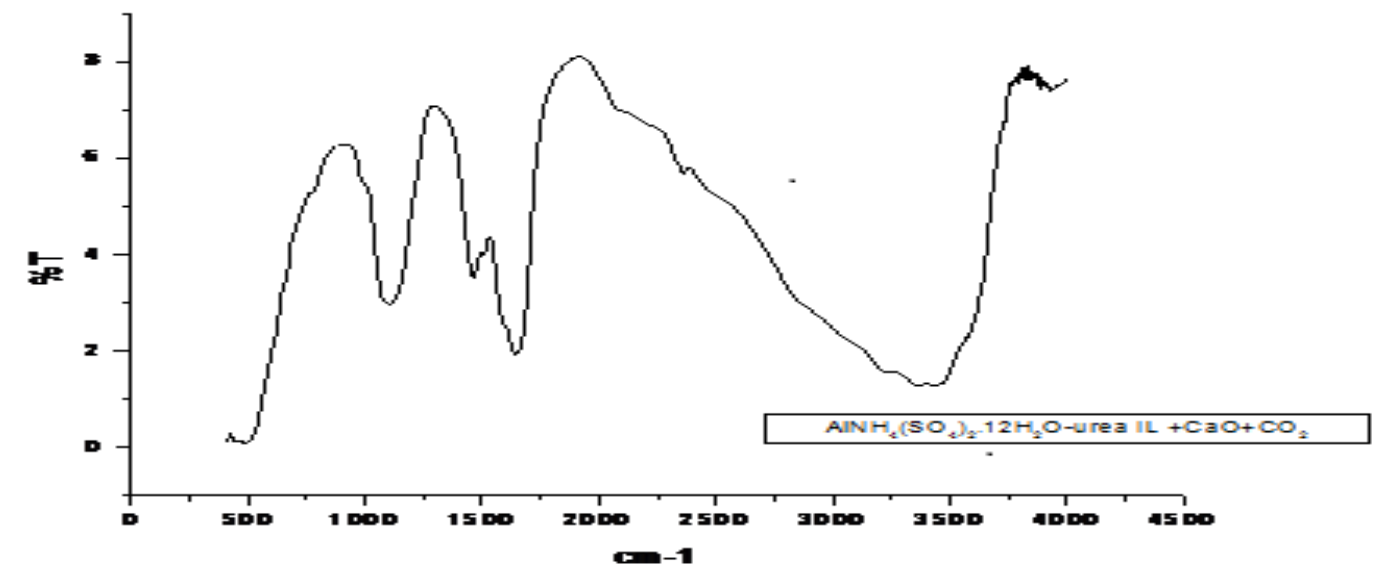

Fig.(4) FTIR vibration bands of $\mathrm{NH}_{4} \mathrm{Al}\left(\mathrm{SO}_{4}\right)_{2} \cdot 12 \mathrm{H}_{2} \mathrm{O}$-urea IL containing $\mathrm{CaO}$.

Table (2)

FTIR vibration bands of $\mathrm{NH}_{4} \mathrm{Al}\left(\mathrm{SO}_{4}\right)_{2} .12 \mathrm{H}_{2} \mathrm{O}$.urea containing $\mathrm{CaO}$ before and after bubbling $\mathrm{CO}_{2}$.

\begin{tabular}{|c|c|c|c|c|c|}
\hline$I L$ & $\begin{array}{c}v(\mathrm{~N}-\mathrm{H}) \\
\mathrm{cm}^{-1}\end{array}$ & $\begin{array}{c}\delta(\mathrm{N}-\mathrm{H}) \\
\mathrm{cm}^{-1} \\
\end{array}$ & $\begin{array}{c}v(C=O) \\
\mathrm{cm}^{-1}\end{array}$ & $\begin{array}{c}v_{s}(N-C-N) \\
\mathrm{cm}^{-1}\end{array}$ & $\begin{array}{c}v_{a s}(N-C-N) \\
c^{-1}\end{array}$ \\
\hline $\begin{array}{c}\mathrm{Al}\left(\mathrm{SO}_{4}\right)_{2} . \mathrm{NH}_{4} \cdot 12 \mathrm{H}_{2} \mathrm{O} . \text { urea. } \\
\mathrm{CaO}\end{array}$ & 3230 & 1550 & 1645 & 1132 & 1396 \\
\hline $\begin{array}{c}\mathrm{Al}\left(\mathrm{SO}_{4}\right)_{2} \cdot \mathrm{NH}_{4} \cdot 12 \mathrm{H}_{2} \mathrm{O} \text {.urea. } \\
\mathrm{CaO}+\mathrm{CO}_{2}\end{array}$ & 3244 & 1540 & 1626 & 1107 & 1462 \\
\hline
\end{tabular}

Powdered calcium oxide when added to $\mathrm{Al}$ $\left(\mathrm{NO}_{3}\right)_{3} .9 \mathrm{H}_{2} \mathrm{O}$-urea ionic liquid formed clear solution and after bubbling carbon dioxide showed the vibrational bands as in Fig.(5). In contrast to the observed frequencies of $\mathrm{N}-\mathrm{H}$ stretching in ionic liquids alone, this ionic liquid mixture showed no changes in both $\mathrm{N}-\mathrm{H}$ or $\mathrm{C}=\mathrm{O}$ frequencies which might be taken as indicator for carbon dioxide absorption in agreement with other report ${ }^{[11]}$.

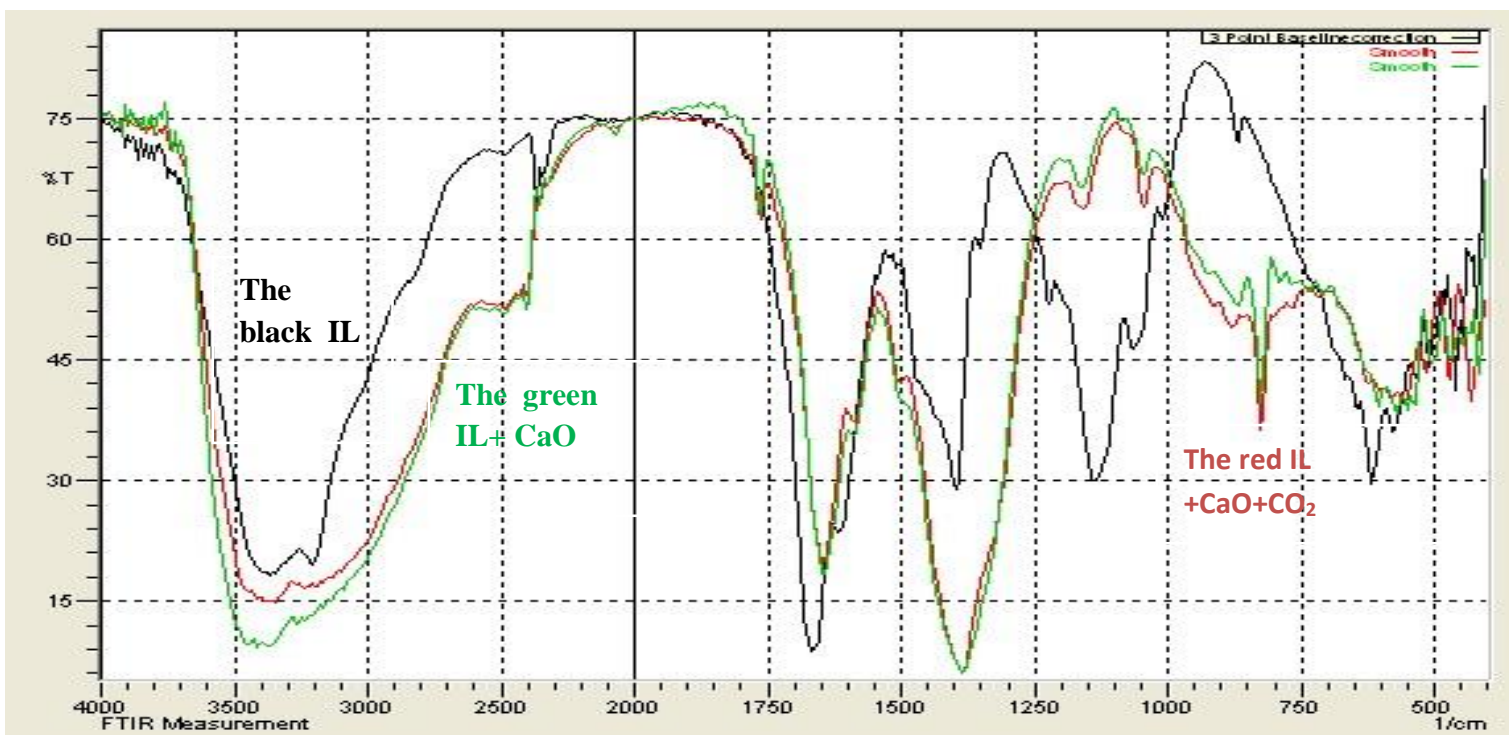

Fig.(5) FTIR spectra overlay to compare between vibrational bands of $\mathrm{Al}\left(\mathrm{NO}_{3}\right)_{3} .9 \mathrm{H}_{2} \mathrm{O}$-urea, the black IL alone, the green with $\mathrm{CaO}$ and the red with capturing $\mathrm{CO}_{2}$. 
Aluminum chloride - urea ionic liquid ${ }^{[14]}$ bubbled with carbon dioxide observed to have some changes in the vibrational mode of the amide and carbonyl groups in addition to the appearance of a new band at $\left(1655 \mathrm{~cm}^{-1}\right.$, Fig.(6). The latter frequency could be arise from a splitting in the carbonyl group vibrational mode. Amide bending vibration band at $1504 \mathrm{~cm}^{-1}$ Table (3) showed an increase in its intensity with similar increase in the intensity of $\mathrm{C}=\mathrm{O}$. The changes in the backbone vibrational mode of urea molecule $(\mathrm{N}-\mathrm{C}-\mathrm{N})$. The changes would indicate an interaction of carbon dioxide with urea of the ionic liquid.

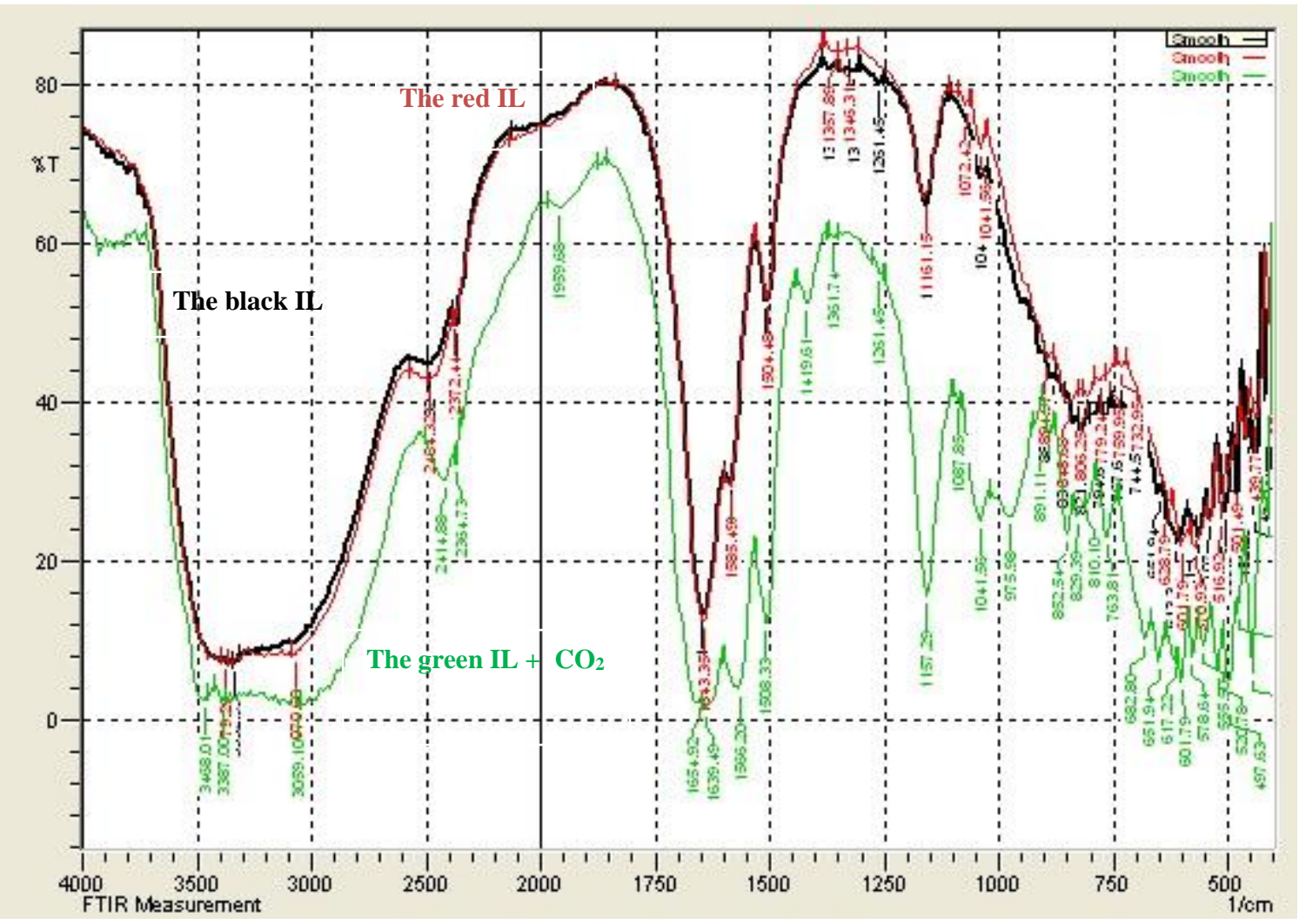

Fig.(6) FTIR spectra of $\mathrm{AlCl}_{3}$-urea IL, (black) IL alone,(red) before bubbling $\mathrm{CO}_{2}$ and (green) after bubbling $\mathrm{CO}_{2}$.

Table (3)

FTIR vibrational bands of $\mathrm{AlCl}_{3}$ - urea IL and with capturing $\mathrm{CO}_{2}$.

\begin{tabular}{|c|c|c|c|c|c|}
\hline$I L$ & $\begin{array}{c}v(\mathrm{~N}-\mathrm{H}) \\
\mathrm{cm}^{-1}\end{array}$ & $\begin{array}{c}\delta(\mathrm{N}-\mathrm{H}) \\
\mathrm{cm}^{-1}\end{array}$ & $\begin{array}{c}v(C=O) \\
\mathrm{cm}^{-1}\end{array}$ & $\begin{array}{c}v_{s}(N-C-N) \\
c^{-1}\end{array}$ & $\begin{array}{c}v \text { as }(N-C-N) \\
\mathrm{cm}^{-1}\end{array}$ \\
\hline $\mathrm{AlCl}_{3}$ - urea & $\begin{array}{l}3333 \\
3270\end{array}$ & $\begin{array}{l}1585 \\
1504\end{array}$ & 1643 & 1161 & 1320 \\
\hline $\mathrm{AlCl}_{3}-$ urea $+\mathrm{CO}_{2}$ & $\begin{array}{l}3498 \\
3387 \\
3059\end{array}$ & $\begin{array}{l}1566 \\
1508\end{array}$ & $\begin{array}{l}1655 \\
1639\end{array}$ & 1157 & 1350 \\
\hline
\end{tabular}

Aluminum chloride-acetamide ionic liquid ${ }^{[14]}$ bubbled with carbon dioxide showed FTIR Fig.(7) without an effect on the vibration modes of $\mathrm{AlCl}_{3}$-acetamide ionic liquid indicating no interaction of carbon dioxide with amide nor dissolved carbon dioxide in ionic liquid. 


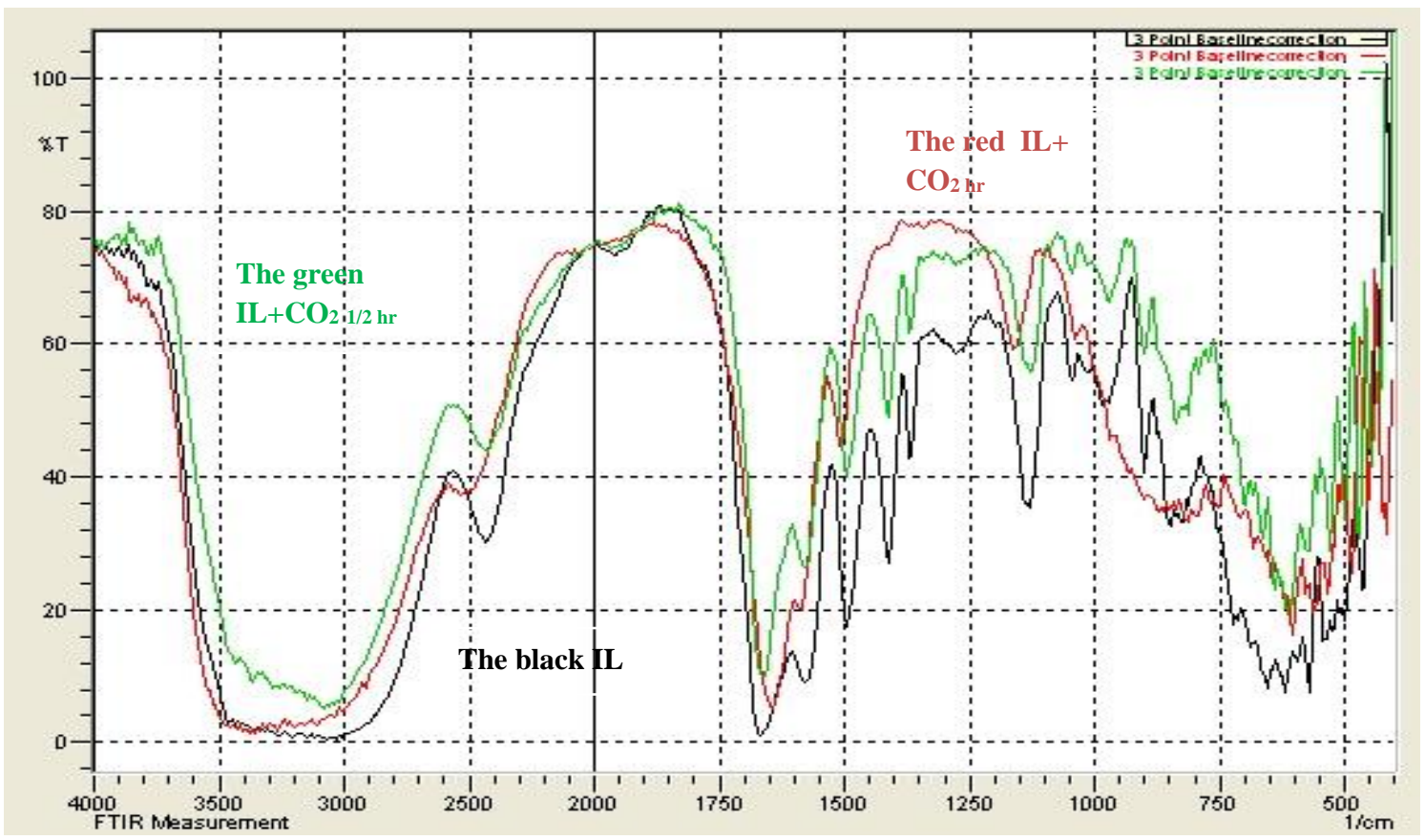

Fig.(7) FTIR vibrational bands of AlCl $\mathrm{A}_{3}$-acetamide IL,( black) IL alone, (green)after bubbling $\mathrm{CO}_{2}$ for half an hour and (red) bubbling $\mathrm{CO}_{2}$ for an hour.

To differentiate between the effect of water in the added $\mathrm{NaOH}_{\text {aq }}$ to $\mathrm{NH}_{4} \mathrm{Al}\left(\mathrm{SO}_{4}\right)_{2} \cdot 12 \mathrm{H}_{2} \mathrm{O}-$ urea IL and solid $\mathrm{NaOH}$ effect , an equivalent amount of water ( 3 drops) were added to the above IL. Examination of FTIR Fig.(8) vibrational modes before and after bubbling $\mathrm{CO}_{2}$ indicated a broaden effect on the high vibrational bands above $2500 \mathrm{~cm}^{-1}$. This broad band returned its shape (as in IL alone) after bubbling $\mathrm{CO}_{2}$ gas in the same trend as with mixture of added $\mathrm{NaOH}_{\mathrm{aq}}$ with IL. However, the carbonyl group vibrational band $1662 \mathrm{~cm}^{-1}$ seems to have no clear effect by the addition of water nor the vibrational band of sulfate group at $1103 \mathrm{~cm}^{-1}$. These two bands showed clear effect in the case of the mixture of $\mathrm{NaOH}_{\mathrm{aq}}$ with IL Fig.(9) which indicate that both water and $\mathrm{NaOH}$ have affected the vibrational band of IL while the IL returned its initial vibrations after bubbling $\mathrm{CO}_{2}$ which indicate an interaction of added water or $\mathrm{NaOH}_{\text {aq }}$ to IL. This interaction could result in forming carbonic acid as follow:-

$$
\begin{aligned}
& \mathrm{H}_{2} \mathrm{O}+\mathrm{CO}_{2} \rightarrow \mathrm{H}_{2} \mathrm{CO}_{3} \\
& \mathrm{OH}^{-}+\mathrm{CO}_{2} \rightarrow \mathrm{HCO}_{3}^{-}
\end{aligned}
$$




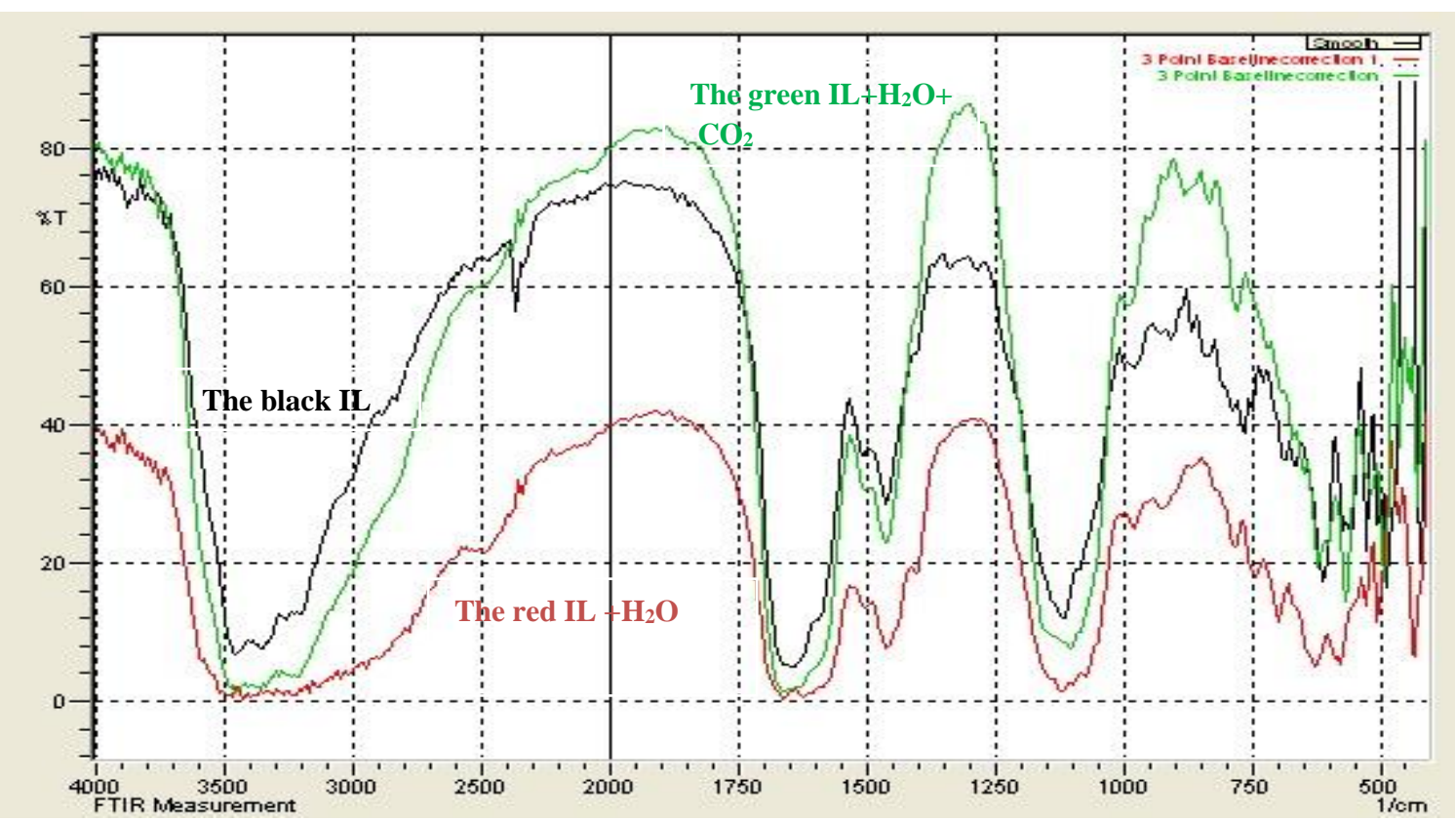

Fig.(8) FTIR vibrational bands of $\mathrm{NH}_{4} \mathrm{Al}\left(\mathrm{SO}_{4}\right)_{2} .12 \mathrm{H}_{2} \mathrm{O}$-urea IL, (black) IL alone, (red) with added $\mathrm{H}_{2} \mathrm{O}$ and (green) after bubbling $\mathrm{CO}_{2}$.

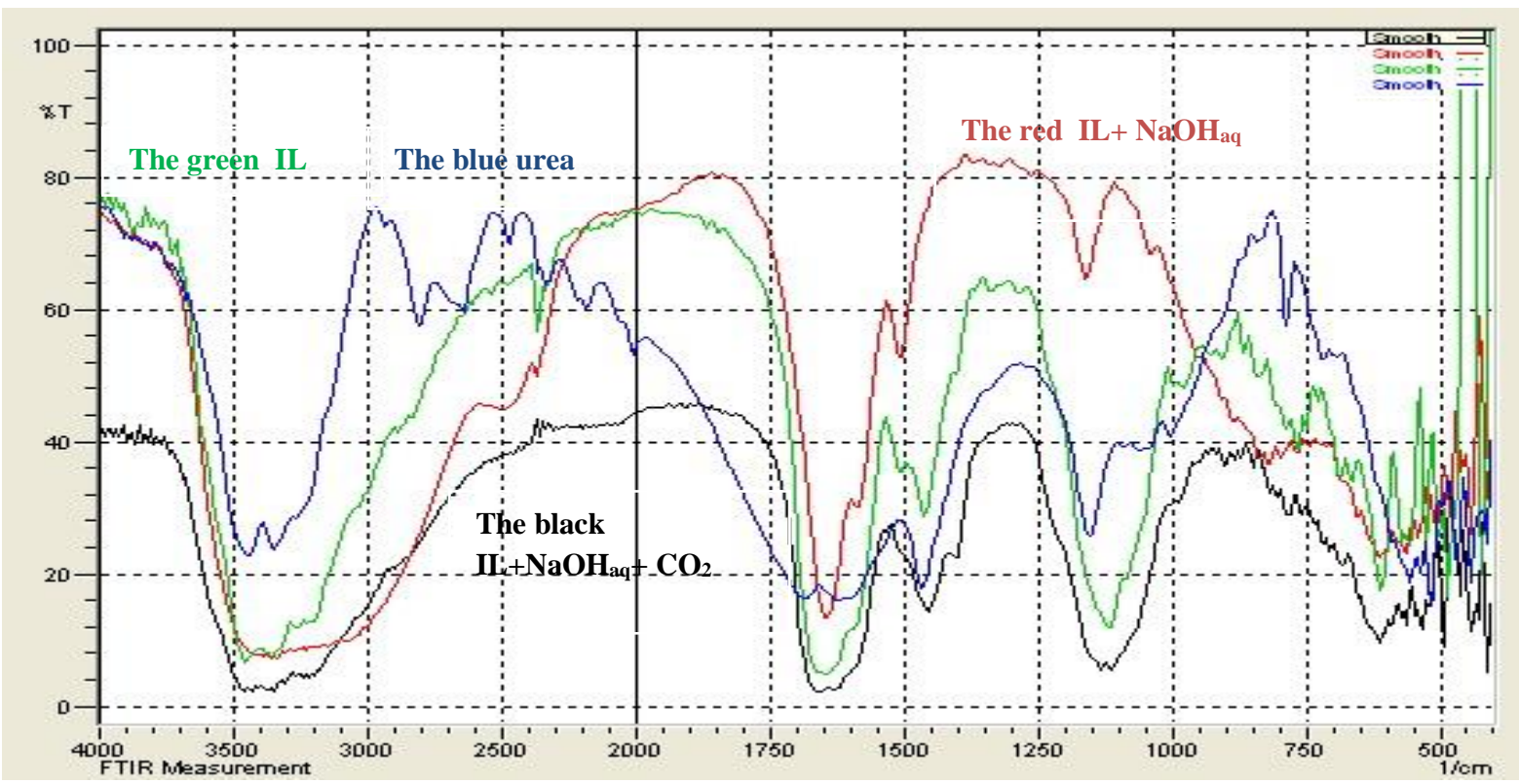

Fig.(9) FTIR vibrational bands of $\mathrm{NH}_{4} \mathrm{Al}\left(\mathrm{SO}_{4}\right)_{2} \cdot 12 \mathrm{H}_{2} \mathrm{O}$-urea IL, (green) IL alone, (red) with $\mathrm{NaOH}_{a q}$, (blue) urea alone and (black) IL with $\mathrm{NaOH}_{\text {aq }}$ after bubbling $\mathrm{CO}_{2}$.

\section{Conclusion}

Carbon dioxide was observed to be absorbed by $\mathrm{NH}_{4} \mathrm{Al}\left(\mathrm{SO}_{4}\right)_{2} \cdot 12 \mathrm{H}_{2} \mathrm{O}$-urea ionic liquid containing aqueous sodium hydroxide solution ,as indicated by the new band at 1666 $\mathrm{cm}^{-1}$ for the carbon dioxide of the carbamate and the disappearance of broad band resulted from the addition of aqueous sodium hydroxide solution to this ionic liquid of the $\mathrm{OH}^{-1}$ stretching indicating the absence of free water molecule in ionic liquid. The resulted bands at the high frequency region related to $\mathrm{N}-\mathrm{H}$ stretching at $\left(3201 \mathrm{~cm}^{-1}, 3348 \mathrm{~cm}^{-1}\right.$ and $3452 \mathrm{~cm}^{-1}$ ) which appeared originally in the ionic liquid before the addition of aqueous sodium hydroxide solution. While in absence of added water the active absorption of carbon dioxide was not observed as no FTIR changes were recorded in the vibration frequencies. Similar new band of a carbon dioxide carbamate vibration was also observed in $\mathrm{AlCl}_{3}$-urea alone at $1655 \mathrm{~cm}^{-1}$ similar to the 
reported frequency in [mim] $\mathrm{PF}_{6}$ ionic liquid [16] and accepted as an indication of carbon dioxide absorption in ionic liquid. Similarly dissolved carbon dioxide was not observed in the FTIR bands. However, with $\left(\mathrm{AlCl}_{3}-\right.$ Acetamide) the weak absorption of carbon dioxide could be related to the less basic amide group as the lone pair is closely withdraw to the carbon atom to enhance its electronic density due to the interaction of oxygen atom of its carbonyl group with Aluminum in the $\left[\mathrm{AlCl}_{2} \text {-Acetamide }\right]^{+}$cationic species of the ionic liquid ${ }^{[14]}$. This is not the case with $\mathrm{AlCl}_{3}$-urea, as two amide group are bonded to carbonyl group of urea, thereby providing good electron density on the amide group than on the amide group of acetamide. This will afford a reaction of more basic amide group with carbon dioxide forming carbamate $(\mathrm{N}$ carboxy urea).

\section{References}

[1] Anthony Costello; Mustafa Abbas; Adriana Allen and Sarah Ball; "Managing the health effects of climate change"; The Lancent Commissions. Vol. 373, pp. 1659 1663, 2009.

[2] Jian-Rong Li; Yuguang Ma; M. Colin Mc Carthy; Julian Sculley; Jiamei Yu; HaeKwon Jeong; Perla B. Balbuena and HongCai Zhou; "Carbon dioxide capture-related gas adsorption and separation in metalorganic frameworks"; coordination chemistry review; Lett. Vol. 255, pp. 17911823, 2011.

[3] Oyenekan, B. A. and Rochelle, G.T.; "Energy performance of stripper configurations for $\mathrm{CO}_{2}$ capture by aqueous amines"; Ind. Eng. Chem. Res. Lett.Vol. 45 (8), pp. 2457-2466, 2006.

[4] Fisher, K.S.; Rochelle, G.T.; Ziaii, S. and Schubert, C.; "Advanced amine solvent formulations and process integration for near-term $\mathrm{CO}_{2}$ capture success"; Trimeric Corporation, Pennsylvania; Vol. 104, pp. 6, 2007.

[5] Dawodu, O. F. and Meisen, A.; "Degradation alkanolamine blends by carbon dioxide"; Can J. Chem. Eng. Lett. Vol. 74 (6), pp. 960-966, 1996.
[6] Jalili, A.H.; Mehdizadeh, A.; Shokouhi, M.; Sakhaeinia, H. and Taghikhani,V., "Solubility of $\mathrm{CO}_{2}$ in 1-(2-hydroxyethyl)-3 methylimidazolium ionic liquids with different anions"; J. Chem. Thermodyn. Lett. Vol. 42 (6), pp. 787-791, 2010.

[7] Sanchez, L.M.G., Meindersma, G.W. and de Haan, A.B., "Kinetics of absorption of $\mathrm{CO}_{2}$ in amino-functionalized ionic liquids", Chem. Eng. J., Vol.166 (3), pp. 1104-1115, 2011.

[8] Yanqiang Zhang; Suojiang Zhang; Xingmei Lu; Qing Zhou; Wei Fan; and Xiang Ping Zhang; "Dual AminoFunctionalised Phosphonium Ionic Liquids for $\mathrm{CO}_{2}$ Capture"; Chem.Eur. Lett. Vol. 15, pp. 3003 -3011, 2009.

[9] Almantariotisa, D.; Fandĩnoa, O.; Coxama, J-Y. and Costa Gomesa, M.F.; "Direct measurement of the heat of solution and solubility of carbon dioxide in 1-hexyl-3-methylimidazoliumbis

[trifluoromethylsulfonyl] amid and 1octyl-3-methylimidazoliumbis

[trifluoromethylsulfonyl] amide, International Journal of Greenhouse Gas Control"; International Journal of Greenhouse Gas Control. Lett. Vol. 10, pp. 329-340, 2012.

[10] Jennifer L. Anthony; Sudhir N.V.K. Aki; Edward J. Maginn and Joan F. Brennecke; "Feasibility of using ionic liquids for carbon dioxide capture"; Energy and Envoriment, Vol. 4 , pp. 105-115, 2004 .

[11] Joan F. Brennecke and Edward J. Maginn;" Why Is $\mathrm{CO}_{2}$ So Soluble in Imidazolium-Based Ionic Liquids?"; $J$. AM. CHEM. SOC. Lett. Vol. 126, pp. 5300-5308, 2004.

[12] Deanna, M. D. Alessandro; Berend Smit; and Jeffrey, R. Long; "Carbon Dioxide Capture: Prospects for New Materials"; angewantde chemie. Lett. Vol. 49, pp. 6058-6082, 2010.

[13] Zena N. Al-Qudsi and Hadi M. A. Abood;" The Electronic Transition Behavior $\mathrm{Cr}$ (III), Fe (III), Fe (II) and Ni (II), Transition Metal Cations In Ammonium Alum-Urea Room Temperature Ionic Liquid"; Journal of AlNahrain University; Vol. 16 (3), September, pp. 46-55, 2013. 
[14] Abood, H.; Abbott, A.; Ballantyne and Ryder, K.; " $\mathrm{AlCl}_{3}$-Amid systems-ionic liquids with metal containing cations"; Chem. Commun. Lett. Vol. 47, pp. 35233525, 2011.

[15] Binin, A.; "Metal Organic Frameworks (MOFs) for $\mathrm{CO}_{2}$ capture"; New Orleans., Vol.38, pp. 7-9, 2008.

[16] Eleanor D. Bates; Rebecca D. Mayton; Ioanna Ntai and James H. Davis, Jr.;"CO 2 Capture by a Task-Specific Ionic Liquid"; J.AM.CHEM, Lett. Vol. 6, pp. 124, 2002.

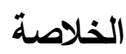

تم دراسة اربعة انواع من السوائل الايونية لغرض دراسة

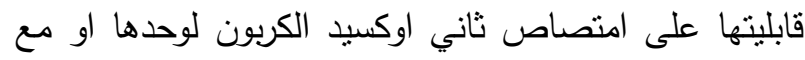

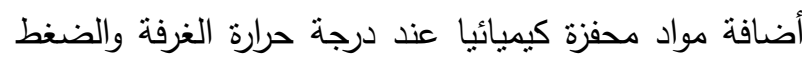
الجوي. وقد وجد بأن السائل الايوني نترات الامونيوم الالمنيوم المائية - يوريا مع اضافة اوكسيد الكالسيوم او كبريتات الامونيوم الالمنيوم المائية - يوريا مع اضافة هيدروكسيد الهيد

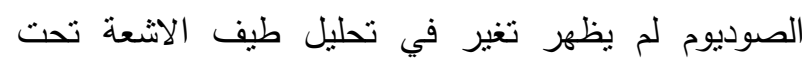

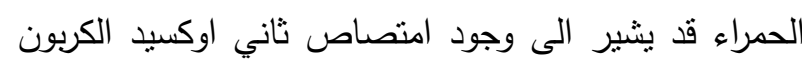

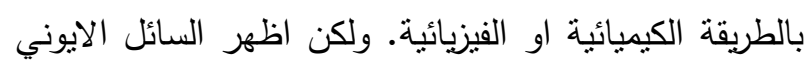

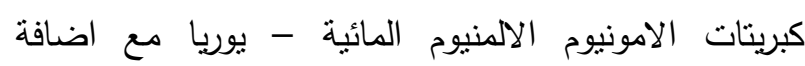
هيدروكسيد الصوديوم المائي اظهر تغير في طيف الاشعة الأئن تحت الحمراء يشير الى وجود امنصاص كيمياوي لناني اوكسيد الكربون. بالأضافة الى ذلك فقد وجد بأن السائل الايوني كلوريد الالمنيوم - يوريا ذو قابلية على امتصاص بلاص

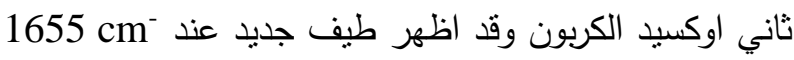
1 قابلية هذا السائل اكبر من قابلية السائل الايوني كلوريد الالمنيوم - اسيتامايد في قنص ثاني اوكسيد الكربون. 